The impact of the COVID-19 pandemic on the third sector and carers in the UK Jones, Carys

\title{
International Journal of Care and Caring
}

DOI:

https://doi.org/10.1332/239788221X16171137895838

Published: 01/08/2021

Peer reviewed version

Cyswllt i'r cyhoeddiad / Link to publication

Dyfyniad o'r fersiwn a gyhoeddwyd / Citation for published version (APA):

Jones, C. (2021). The impact of the COVID-19 pandemic on the third sector and carers in the UK. International Journal of Care and Caring, 5(3), 529-534.

https://doi.org/10.1332/239788221X16171137895838

\footnotetext{
Hawliau Cyffredinol / General rights

Copyright and moral rights for the publications made accessible in the public portal are retained by the authors and/or other copyright owners and it is a condition of accessing publications that users recognise and abide by the legal requirements associated with these rights.

- Users may download and print one copy of any publication from the public portal for the purpose of private study or research

- You may not further distribute the material or use it for any profit-making activity or commercial gain

- You may freely distribute the URL identifying the publication in the public portal ?
}

Take down policy

If you believe that this document breaches copyright please contact us providing details, and we will remove access to the work immediately and investigate your claim. 


\title{
The impact of the COVID-19 coronavirus pandemic on the third sector and carers in the United Kingdom
}

\author{
Carys Jones \\ Bangor University, United Kingdom
}

\begin{abstract}
:
The coronavirus outbreak that emerged at the end of 2019 has had a significant, ongoing, global impact. This article discusses the impact on the third sector in the UK, and carers who use third sector services.
\end{abstract}

Key words:

COVID-19; third sector; nonprofit organisations; carers

Word count:

1,834 (exc. References) 


\section{Introduction}

In the UK, there are 6.5 million carers providing unpaid support to friends and family (Buckner and Yeandle, 2015). The majority of the care provided is for older adults, often by spouses who are themselves at an advanced age. The 'third sector' includes social enterprises, charities, voluntary organisations, community groups, faith organisations, and co-operatives. Although they operate independently of government, third sector organisations in the UK often work closely with local authorities and public services to promote social action and empower communities. Third sector organisations that support carers aim to improve support through activities such as offering advice, information and support; signposting to respite and other services; providing social opportunities; and campaigning for carers' rights. In 2018 the UK Government released a civil society strategy that acknowledged the role of the third sector in addressing societal challenges such as social care provision, community integration and healthy ageing. This outlined the Government's approach to working collaboratively, across sectors, to maximise efficient use of resources (Cabinet Office, 2018). While the long-term impact of the COVID-19 pandemic is as yet unknown, in the short-term it has changed how people live their lives across the world. This article reviews the impact of the pandemic on the third sector in the UK, focusing on carers, and presents opportunities for service redesign to enhance the sustainability of the third sector in a post-pandemic world.

\section{Impact of the COVID-19 pandemic on carers and the third sector}

A survey conducted in June 2020 found that charities anticipated that their total income would be significantly lower in the year ahead, with $34 \%$ believing they would have to reduce services drastically, and $5 \%$ anticipating that they would be forced to close. Only $11 \%$ of the charities responding expected to be able to provide services at the same level as previously (Institute of Fundraising, NCVO \& Charity Finance Group, 2020). Although the UK Government has announced a $f 750$ million support package for charities affected by COVID-19, the income shortfall across the third sector is anticipated to involve billions, rather than millions, of pounds. Despite reduced income and capacity, charities are nevertheless experiencing increased demand for their services, with 63\% reporting higher levels of demand compared to the previous year (Pro Bono Economics, 2020). Demand for support has increased as a direct consequence of the pandemic, due to people experiencing loneliness, social isolation and poorer mental health. During the first lockdown, carers of people with dementia reported spending an extra 92 million hours on caring, with $95 \%$ of carers saying their physical or mental health had worsened and 69\% feeling constantly exhausted (Alzheimer's Society, 2020). The impact of social isolation on carers will also have had a negative impact on their mental wellbeing. The Government advised 'clinically extremely vulnerable' people (e.g. people with cancer and people with severe respiratory conditions) to 'shield', which entailed staying at home and avoiding face-to-face contact 
with other people, apart from going out to exercise or attend medical appointments. Once shielding guidance was relaxed in August 2020, pressure on third sector capacity was exacerbated, as a backlog of carers sought out support services. In the UK, carer assessments are available for carers of adults who are disabled, ill or elderly to assess whether support is needed for the carer e.g. help with transport costs, help with housework, or signposting to information and advice about caring. Postlockdown, there was a need for updated carer assessments and respite services, and many care recipients needed reablement services to help them re-establish skills needed to carry out daily activities that had diminished during lockdown.

\section{Looking ahead to third sector service delivery in a post-pandemic world}

Five priorities for reshaping health and care services beyond the COVID-19 crisis, that are also relevant for the third sector, have been identified by The King's Fund, an independent think tank that aims to improve health and care in England through shaping policy and practice. These priorities are: addressing inequalities and population health; lasting reform for social care; putting the workforce 'centre-stage'; embedding and accelerating digital change; and reshaping the relationship between communities and public services (Charles and Ewbank, 2020).

\section{Addressing inequalities and population health}

The COVID-19 pandemic has disproportionately affected people who already had poorer health outcomes, including older people, people living in deprived areas, and Black, Asian and Minority Ethnic (BAME) groups (Public Health England, 2020). The Marmot review of the impact of COVID-19 on health inequalities calls to 'Build Back Fairer' post-pandemic, and for increased investment in public health policies to address health inequalities and respond to evidence about the social determinants of health (Marmot et al, 2020). Remaining 'mission focused' is essential for third sector organisations, and the importance of targeting delivery of services to those most in need has been identified (for example, supporting the re-emergence of people living with dementia into public spaces). Third sector services operating at a local level, with detailed knowledge of the needs and existing assets of the local community will be well placed to offer support to the people who need it most following the pandemic.

\section{Lasting reform for social care}

Fragmented health and social services support has long been an issue for carers. Delayed hospital discharge of patients while they await a social services assessment is a common problem, but early discharge from hospital can impose caring roles upon carers in ways that are problematic too. In parts of England, Integrated Care Systems (ICS) are in place; these are being rolled out further, with a remit of bringing local organisations together across sectors to collaborate on decision-making 
and to redesign care services to improve population health. Due to austerity policies, local authority spending on social care is lower than it was a decade ago, and the number of jobs in the formal care sector is showing only modest growth, despite increased demand for services (Bottery and Babalola, 2020). Possible explanations for this include: i) the ratio of care recipients to care workers has increased; ii) people with care needs are going without care; or iii) people with care needs are relying more on unpaid carers to meet their needs (Bottery and Babalola, 2020). None of these potential scenarios paints a positive outlook for the sustainability of the social care system in its current form, and The King's Fund has called on the Government to address short-term funding pressures that have arisen due to the COVID-19 pandemic; to bring forward proposals for longer-term investment and reform; and to introduce better pay, improved working conditions and more training for the social care workforce (Charles and Ewbank, 2020).

\section{Putting the workforce centre stage}

Staffing capacity has been reduced in all sectors. A survey of charitable organisations found that in November 2020, a third still had staff on furlough, with implications for their capacity and ability to provide services (Pro Bono Economics, 2020). Attendance levels for non-furloughed staff and volunteers fluctuated over 2020; reasons included people needing to self-isolate due to having coronavirus symptoms, or to follow Government guidance on shielding if they were classed as clinically vulnerable. Volunteers especially may have been affected by the shielding policies for people aged 70+, as compared with other age groups, older people are more likely to volunteer.

The National Health Service (NHS) is the largest employer in the UK, with over 1.5 million staff. Recognising that many NHS staff have unpaid caring commitments outside of their work role has led to the introduction of flexible working policies that allow people with caring responsibilities to remain in employment. The NHS also has forward-thinking policies on volunteers, seeing them 'not as substitutes for, but as partners with, our skilled employed staff' (NHS England, 2014)- an approach to volunteering shared by many third sector organisations. Fostering volunteer networks is a key growth opportunity for the sector.

\section{Embedding and accelerating digital change}

During the pandemic, use of digital technology to socialise and to shop online increased significantly. Many third sector organisations strengthened their online presence and provided webbased support resources. The move to online services offers an opportunity to maintain the workforce capacity of the third sector. Working from home has been encouraged, and older volunteers who would previously have stopped any in-person volunteering due to shielding can still offer valuable support online. Wider use of digital services has drawbacks, however; not everyone has the financial 
resources or technological skills to use these services efficiently. Online fraud, including 'phishing' scams related to COVID-19, have been reported and people less skilled in technology are more vulnerable to these. Third sector organisations can play an important role in training carers and older people in safe use of digital technologies. Accessibility is an important consideration for older service users, including clear navigation, text size and font readability, and making pages compatible with speech-to-text features for users with hearing impairments.

\section{Reshaping the relationship between communities and public services}

Building stronger relationships between public services and communities has been an ambition of the NHS for several years. Involving local volunteers as community health champions can promote social cohesion within communities and also improves volunteers' wellbeing, by increasing their selfesteem and confidence. This local-led, integrated, approach contrasts with current 'top-down' national approaches in much public sector service delivery. Lessons can be drawn from experience in the public sector on reducing procedural barriers in response to the pandemic; there has, for example, been a temporary relaxation of some restrictions on sharing information between health and social care services, to reduce delays in clients receiving vital services (Comas-Herrera et al, 2020). Similar temporary procedural relaxations could be implemented within third sector organisations and across agencies in the public and third sector, to enable faster, more efficient response to carers presenting to services.

\section{Conclusions}

The long-term outlook for the third sector remains uncertain, particularly for smaller organisations that rely on public fundraising for their income. Despite reduced income and capacity to provide services, third sector organisations are facing higher than ever demands. In the short-term, the sector has had to modify how services are delivered, including moving some activities online to continue supporting service users, such as carers. The increased use of technology is beneficial for the third sector workforce as it aligns with guidance to work from home where possible, and allows staff and volunteers to continue to provide services even if they need to self-isolate or shield. Increased use of digital services is not without its challenges, however, and organisations need to ensure their online provision is accessible and suitable for the needs of their service users. Further developing volunteer capacity is an important opportunity for the third sector to build a sustainable workforce, equipped to deliver services in unprecedented COVID-19 times, and beyond. Roles for volunteers include acting as local community champions and working alongside paid staff in public sector organisations. Reforming services with a view to greater integration between public sector organisations and the third sector is 
essential, along with implementing long-term policies that address health inequalities and improve wellbeing for the people who have been the worst affected by the pandemic.

\section{References}

Alzheimer's Society (2020) Worst hit: dementia during coronavirus, London: Alzheimer's Society, https://www.alzheimers.org.uk/sites/default/files/2020-09/Worst-hit-Dementia-during-coronavirusreport.pdf

Bottery, S. and Babalola, G. (2020) Social Care 360, London: The King's Fund, https://www.kingsfund.org.uk/sites/default/files/2020-

05/Social\%20care\%20360\%202020\%20PDF_0.pdf Buckner, L. and Yeandle, S. (2015) Valuing carers 2015: the rising value of carer's support, London: Carers UK.

Cabinet Office (2018) Civil society strategy: Building a future that works for everyone, London.

Charles, A. and Ewbank, L. (2020) The road to renewal: five priorities for health and care, London: The King's Fund, https://www.kingsfund.org.uk/publications/covid-19-road-renewal-health-and-care Comas-Herrera, A., Fernandez, J.L., Hancock, R., Hatton, C., Knapp, M., McDaid, D., Malley, J., Wistow, G. and Wittenberg, R. (2020) 'COVID-19: Implications for the Support of People with Social Care Needs in England', Journal of Aging and Social Policy, 32(4-5). doi: 10.1080/08959420.2020.1759759. Institute of Fundraising, NCVO \& Charity Finance Group (2020) Impact on the charity sector during coronavirus - research report June 2020, London: Institute of Fundraising, NCVO \& Charity Finance Group.

Marmot, M., Allen, J., Goldblatt, P., Herd, E., and Morrison, J. (2020) Build back fairer: The COVID-19 Marmot review, London: The Health Foundation, Institute of Health Equity.

NHS England (2014) NHS England " The NHS five year forward view, London, https://www.england.nhs.uk/publication/nhs-five-year-forward-view/

Pro Bono Economics (2020) PBE November 15-20 Covid Charity Tracker results, London: Pro Bono Economics. https://www.probonoeconomics.com/november-15-20-covid-charity-tracker-surveyresults

Public Health England (2020) Disparities in the risk and outcomes of COVID-19, London: Public Health England, https://assets.publishing.service.gov.uk/government/uploads/system/uploads/attachment_data/file/ 908434/Disparities_in_the_risk_and_outcomes_of_COVID_August_2020_update.pdf

\section{Funding details}

This work was supported by Health and Care Research Wales under Grant SC-16-1273.

\section{Conflict of interest}

The Author declares that there is no conflict of interest. 